\title{
SISTEM PENGOLAHAN DATA NILAI SEBAGAI EVALUASI KUALITAS LULUSAN UNTUK MENGUKUR DAYA SERAP PERGURUAN TINGGI
}

\author{
Rosmawati Dwi*1, Pradana Vicky Hernawan ${ }^{2}$, Rullyanti Putri Rahayu ${ }^{3}$ \\ ${ }^{1,2,3)}$ Program Studi Sistem Informasi Universitas Raharja \\ wmail : rosmawati.dwi@ raharja.info', pradana.vicky@ raharja.info², \\ rullyanti@ raharja.info ${ }^{3}$
}

\begin{abstract}
Abstraksi
Kebutuhan akan tersedianya sekolah untuk seluruh masyarakat dari tahun ke tahun terus meningkat, agar dapat menciptakan generasi yang cerdas dan berkualitas. Terciptanya lulusan yang berkualitas tidaklah semudah membalik telapak tangan, karena membutuhkan pendataan dan monitoring yang baik. Hal paling sederhana untuk mengukur kualitas adalah dengan mengetahui seberapa banyak lulusan disuatu sekolah yang terserap oleh perguruan tinggi negeri, termasuk mengetahui seberapa banyak yang terserap di perguruan tinggi swasta, atau seberapa banyak yang bekerja atau beriwausaha. Salah satu cara mengukur kualitas lulusan adalah dengan cara mengetahui daya serap di perguruan tinggi, hal ini bisa dilakukan dengan proses pengelolaan data berdasarkan nilai raport dan nilai ujian nasional. Kebutuhan ini menjadi permasalahan sendiri yang harus diselesaikan, dengan membangun sebuah sistem pengolahan yang mampu mengukur nilai guna evaluasi lulusan. Dengan menggunakan beberapa metode penelitian seperti metode pengumpulan data, kemudian anlisa kinerja menggunakan metode pisces, dan untuk merancangan gambaran sistem menggunakan metode perancagnan uml yang meliputi usecase diagram, squence diagram, activity diagram, dan mysql digunakan untuk pengolahan basis data, sehingga sistem yang dibuat diharapkan mampu mempuat proses yang lama menjadi lebih cepat, efektif dan efisien. Sehingga dapat menghasilkan sistem yang terintegrasi dengan baik, penelitian ini bermanfaat untuk memudahkan proses evaluasi lulusan dan daya serap perguruan tinggi.
\end{abstract}

Kata kunci: Pengolahan data, kualitas lulusan, daya serap lulusan

\begin{abstract}
The need for the availability of schools for the whole community from year to year continues to increase, in order to create an intelligent and quality generation. The creation of quality graduates is not as easy as turning the palm of the hand, because it requires good data collection and monitoring. The simplest way to measure quality is to find out how many graduates in a school are absorbed by public tertiary institutions, including knowing how much is absorbed in private tertiary institutions, or how many are employed or entrepreneurial. One way to measure the quality of graduates is by knowing the absorption capacity in tertiary institutions; this can be done by the process of managing data based on report cards and national exam scores. This need becomes its own problem that must be solved, by building a processing system that is able to measure the value of the evaluation of graduates. By using several research methods such as data collection methods, then analyzing performance using the Pisces method, and to design a system image using the uml planning method which includes usecase
\end{abstract}


diagrams, squence diagrams, activity diagrams, and mysql used for database processing, so that the system created is expected able to load the old process faster, more effective and efficient. So that it can produce a well-integrated system, this research is useful to facilitate the process of evaluating graduates and the absorption of universities.

Keywords: Data processing, graduates quality, absorption ability of draduates

\section{PENDAHULUAN}

Proses pendidikan di sekolah merupakan kegiatan yang komplek, meliputi berbagai komponen yang berkaitan satu sama lain. Apabila usaha pendidikan hendak dilaksanakan secara terencana maka berbagai komponen perlu dikaji dan dikembangkan, sehingga mekanisme antara komponen itu secara menyeluruh dapat membawa hasil yang maksimal. Upaya peningkatan mutu pendidikan pada semua jenjang merupakan sasaran pendidikan nasional. Oleh sebab itu berbagai upaya untuk meningkatkan mutu pendidikan banyak dilakukan, baik berkenaan dengan peningkatan mutu guru, perbaikan sarana dan prasarana pendidikan maupun penyempurnaan kurikulum, serta proses belajar mengajar. Keseluruhannya dilakukan guna mendapatkan hasil yang lebih baik.

Penilaian adalah rangkaian kegiatan untuk memperoleh, menganalisa, dan menafsirkan data tentang proses dan hasil belajar peserta didik yang dilakukan secara sistematis, akurat dan berkesinambungan dengan menggunakan alat pengukur tertentu, seperti soal dan lembar pengamatan, sehingga menjadi informasi yang bermakna dalam pengambilan keputusan berkaitan dengan pencapaian kompetensi peserta didik [1]. Penilaian merupakan proses pengumpulan dan pengolahan informasi untuk mengukur pencapaian hasil belajar peserta didik [3]. kualitas dapat diartikan sebagai tingkat atau ukuran kesesuaian suatu produk dengan pemakainya, dalam arti sempit kualitas diartikan sebagai tingkat kesesuaian produk dengan standar yang telah ditetapkan [5].

Kualitas adalah keseluruhan ciri dan sifat dari suatu produk atau pelayanan yang berpengaruh pada kemampuannya untuk memuaskan kebutuhan yang dinyatakan atau yang tersirat [7]. Ketersediaan informasi yang cepat dan akurat serta didukung dengan penerapan sistem yang optimal menjadi kelebihan sendiri harus dimiliki setiap perusahaan [2]. Perancangan Sistem adalah suatu kegiatan membuat desain teknis berdasarkan kegiatan pada waktu proses analisis. Perancangan disini dimaksudkan suatu proses pemahaman dan peran suatu sistem informasi berbasis komputer[4].

\section{METODE PENELITIAN}

Metode penelitian merupakan suatu tata cara atau kegiatan pelaksanaan penelitian rangka untuk mengumpulkan informasi atau data serta melakukan investigasi terhadap data yang telah didapatkan tersebut [6]. yang didasari oleh asumsi-asumsi dasar, pandangan-pandangan filosofis dan ideologis, pertanyaan dan isu-isu yang dihadap. Suatu penelitian mempunyai rancangan penelitian tertentu. Rancangan ini menggambarkan prosedur atau langkah-langkah yang harus ditempuh, waktu penelitian, sumber data dan kondisi arti untuk apa data dikumpulkan dan dengan cara bagaimana data tersebut dihimpun dan diolah untuk dianalisa dalam pembuatan laporan. Metode 
observasi adalah cara yang digunakan dalam penelitian yaitu dengan mendatangi instansi terkait guna melihat dan menganalisa langsung kendala yang terjadi. Metode wawancara dalah melakukan proses tanya dan jawab dengan stakeholder atas penelitian ini, baik permasalahan yang ada dan juga solusinya.

\subsection{Metode Analisis Data}

Pada penelitian ini, metode analisa dilakukan dengan langkah-langkah melakukan pengamatan dan analisa terhadap sistem yang berjalan saat ini, serta menentukan UML (Unified Modeling Language) yang meliputi use case diagram, activity diagram, sequence diagram.

\section{HASIL DAN PEMBAHASAN}

Untuk dapat menggambarkan prosedur secara keseluruhan diperlukan bebrapa tahapan analisa sebagai bentuk pengumpulan informasi guna mendapatkan model yang sesuai dengan kebutuhan dan mampu memberikan solusi dengan cepat secara efektif dan efisien, mulai dari tahapan pengumpulan informasi dan kebutuhan, analisa dokumen, merancangan hubungan antar dokumen sampai dengan merancang model diagram database dan model rancangan sistem [8][9]. Beberapa tahapan yang dimaksud sampai dengan model ranangan yang diciptakan dapat dilihat pada gambar 1,2,3,4,5.

\subsection{Use Case Diagram Yang Berjalan}

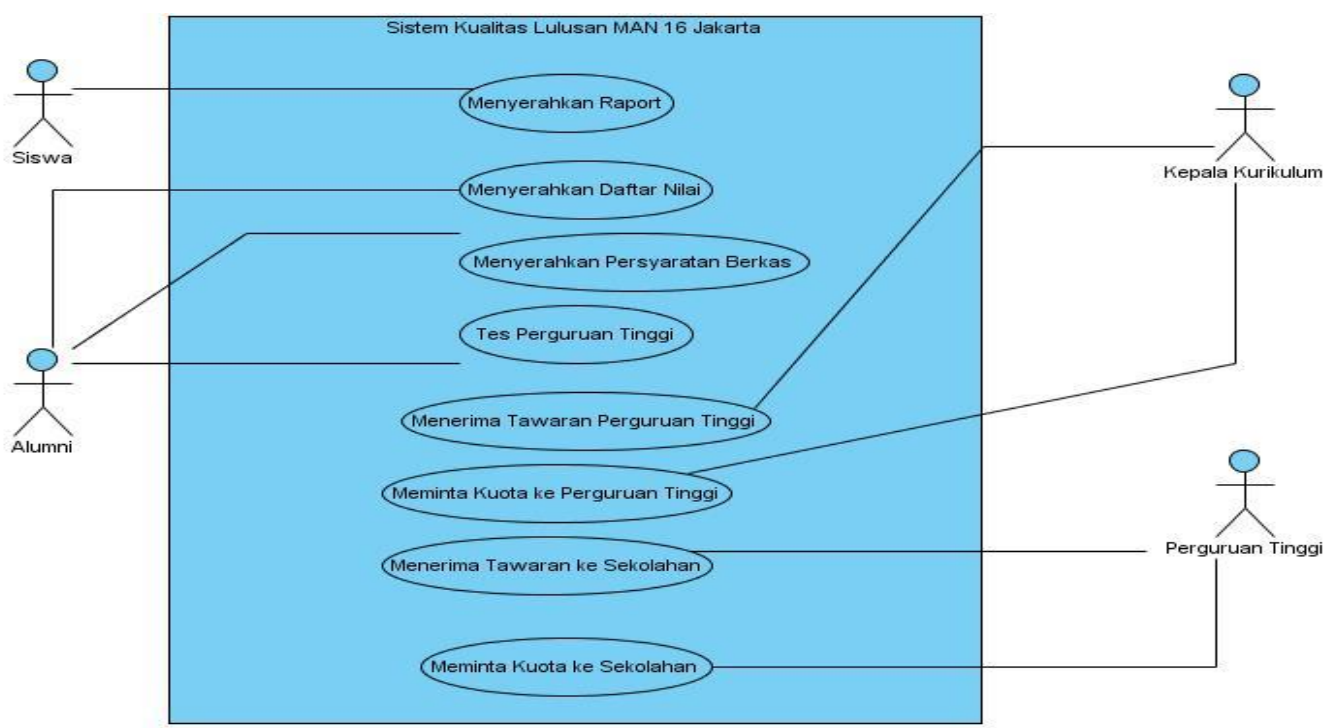

Gambar 1. Use Case Diagram

Berdasarkan gambar use case diagram (gambar 1) yang berjalan, sistem mencakup seluruh kegiatan terkait kualitas lulusan. Terdapat 4 (Empat) Actor yang melakukan kegiatan yaitu Siswa, Alumni, Kepala Kurikulum, dan Perguruan Tinggi yang berfungsi menyerahkan raport, menyerahkan daftar nilai, menyerahkan persyaratan berkas, tes perguruan tinggi, menerima tawaran perguruan tinggi, meminta kuota perguruan tinggi, menerima tawaran ke sekolah, meminta kuota ke sekolah. Terdapat juga 8 (delapan) use case yang merupakan proses yang terjadi pada sistem berjalan yaitu menyerahkan raport melibatkan kepala kurikulum, menyerahkan daftar nilai melibatkan perguruan tinggi, menerima tawaran perguruan tinggi, meminta kuota perguruan tinggi, menerima tawaran ke sekolahan, meminta kuota ke sekolahan. 


\subsection{Activity Diagram Yang Berjalan}

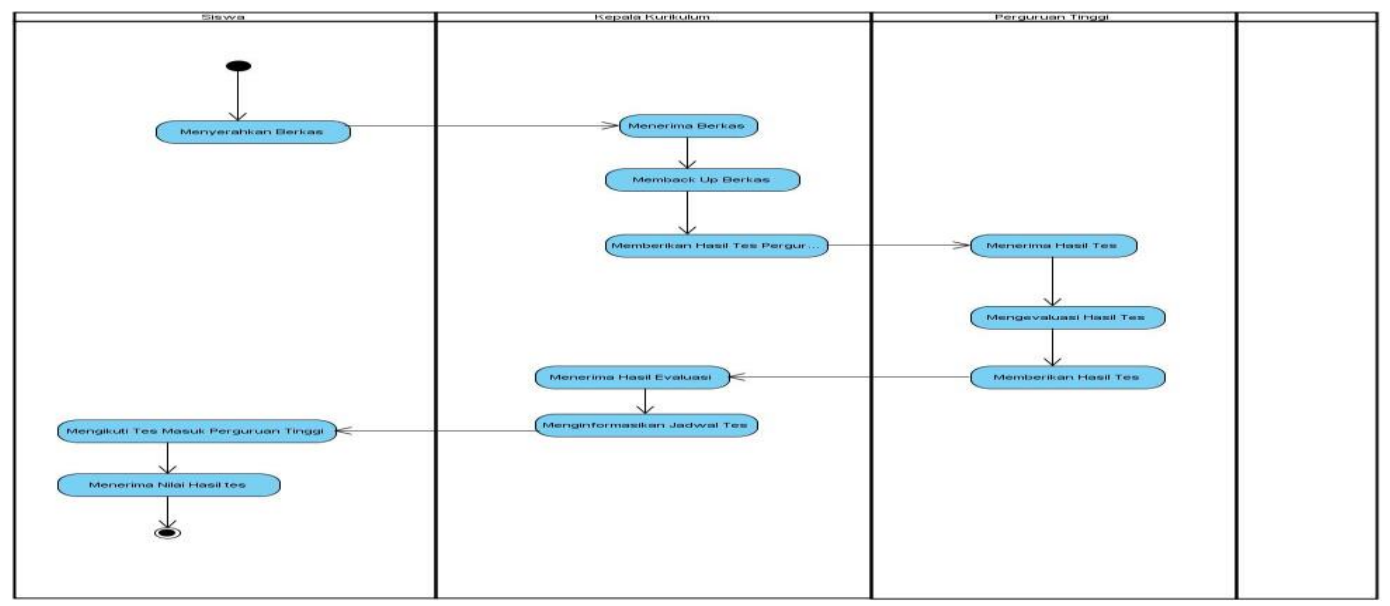

Gambar 2. Activity Diagram

Berdasarkan gambar activity diagram (gambar 2) yang berjalan, sistem mencakup seluruh kegiatan terkait kualitas lulusan. Sistem ini melibatkan 3 (tiga) actor yaitu, siswa menyerahkan raport, Kepala Kurikulum menerima berkas, Membackup Berkas, Memberikan hasil perguruan tinggi, menerima hasil tes dari sekolahan, mengevaluasi hasil tes, memberikan hasil tes, menerima hasil evaluasi dari perguruan tinggi, kepala kurikulum menginformasikan jadwal tes dari perguruan tinggi, siswa mengikuti tes masuk perguruan tinggi, dan menerima hasil tes.

\subsection{Squence Diagram Yang Berjalan}

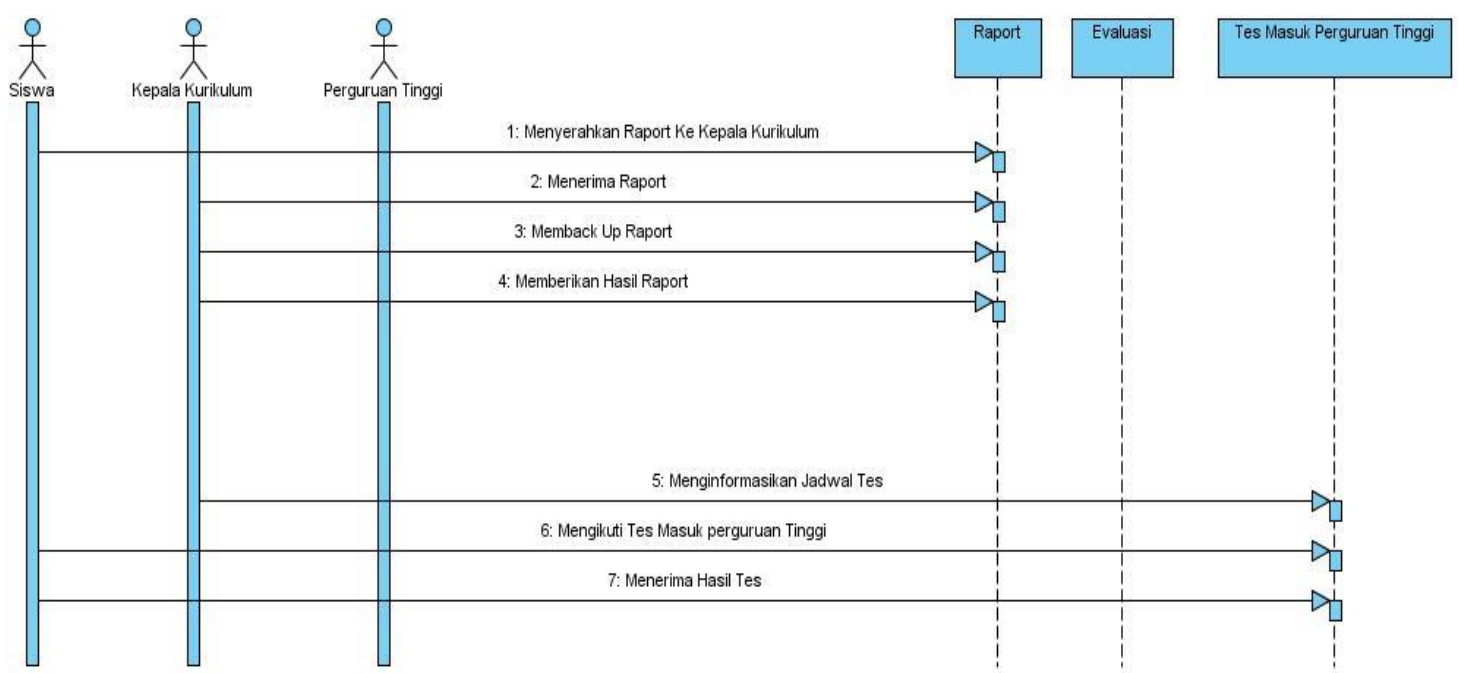

Gambar 3. Squence Diagram

Berdasarkan gambar sequence diagram (gambar 3) yang berjalan, terlihat 3 (tiga) actor yang melakukan kegiatan diantaranya: siswa, kepala kurikulum dan perguruan tinggi, yang akan menyelesaikan 7 message spesifikasi dari komunikasi antar objek yang memuat informasi-informasi tentang aktifitas yang terjadi, yaitu menyerahkan raport ke kepala sekolah, menerima raport, membackup raport, memberikan hasil raport, menginformasikan jadwal tes, mengikuti tes masuk perguruan tinggi, menerima hasil tes. 
Rancangan diatas (gambar 1, 2, 3) merupakan gambaran yang berjalan dimana pada tahapan ini melibatkan beberapa pemberkasan. merupakan proses yang terjadi pada sistem berjalan yaitu menyerahkan raport melibatkan kepala kurikulum, menyerahkan daftar nilai melibatkan perguruan tinggi, menerima tawaran perguruan tinggi, meminta kuota perguruan tinggi, menerima tawaran ke sekolahan, meminta kuota ke sekolahan.

\subsection{Class Diagram}

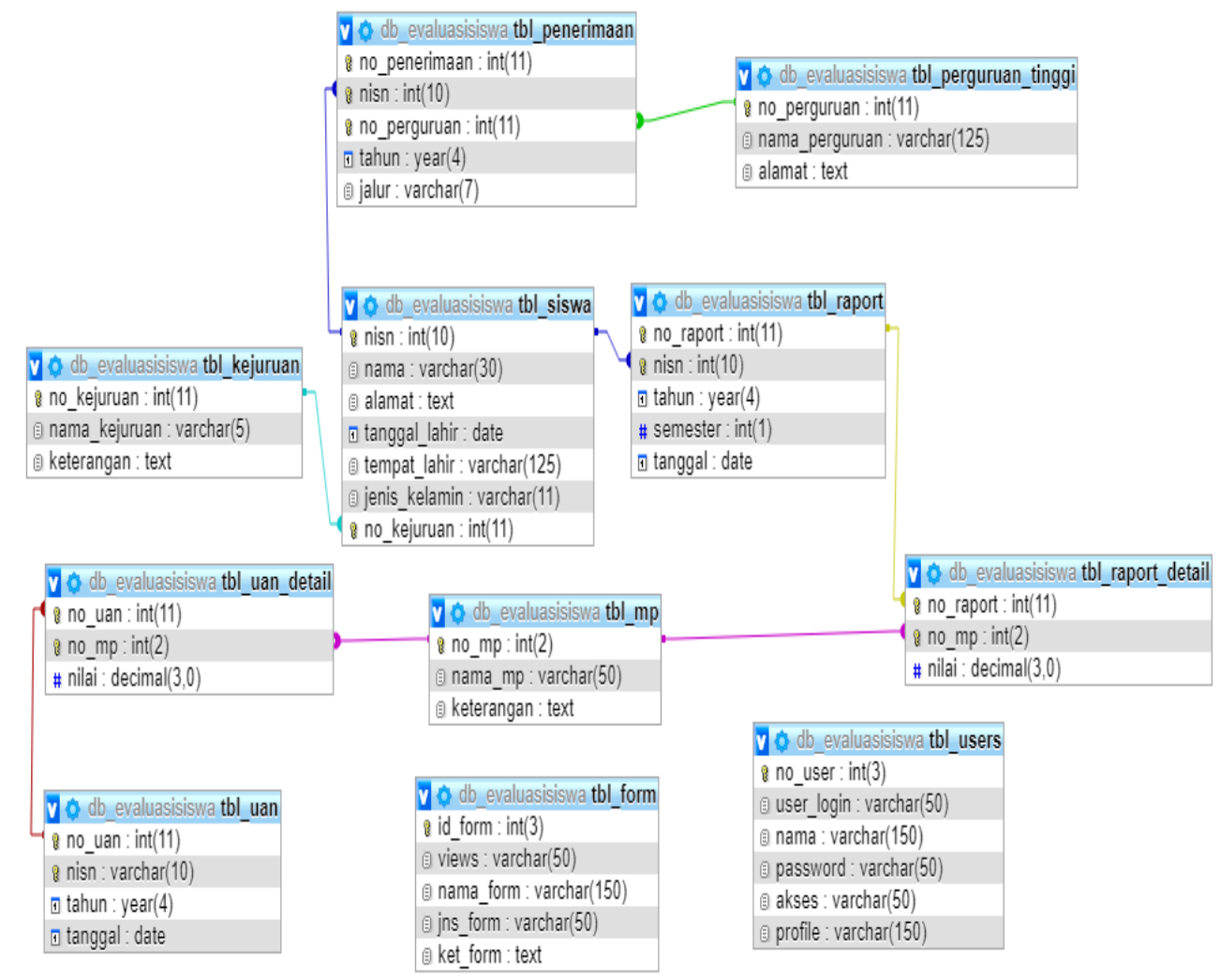

Gambar 4. Class Diagram

Berdasarkan gambar class diagram (gambar 4) yang berjalan saat ini sistem mencakup seluruh kegiatan. Terdapat 11 (sebelas) class yaitu tbl_siswa, tbl_kejuruan, tbl_mp, tbl_perguruan_tinggi yang merupakan tabel master, tbl_raport, tbl_uan, tbl_penerimaan sebagai tabel transaksi, dan juga tbl_raport_detail dan tbl_uan_detail sebagai table histori, juga terdapat tabel user yang merupakan tabel akses untuk masuk ke dalam system dan table form menyimpan semua pengaturan.

Berdasarkan gambar class diagram (gambar 4) diatas dapat dilihat dengan jelas bahwa tingkat hubungan tbl_perguruan_tinggi dan tbl_penerimaan yaitu one to many (1:M), tingkat hubungan tbl_siswa dan tbl_penerimaan yaitu one to many $(1: \mathrm{M})$, ), tingkat hubungan tbl_siswa dan tbl_raport yaitu one to many $(1: \mathrm{M})$, tingkat hubungan tbl_siswa dan tbl_kejuruan yaitu one to many (1:M), tingkat hubungan tbl_mp dan tbl_raport_detail yaitu one to many $(1: \mathrm{M})$, tingkat hubungan tbl_mp dan tbl_uan_detail yaitu one to many (1:M), tingkat hubungan tbl_raport dan tbl_raport_detail yaitu one to one (1:1), tingkat hubungan tbl_mp dan tbl_uan_detail yaitu one to one (1:1) 


\subsection{Use Case Diagram Usulan}

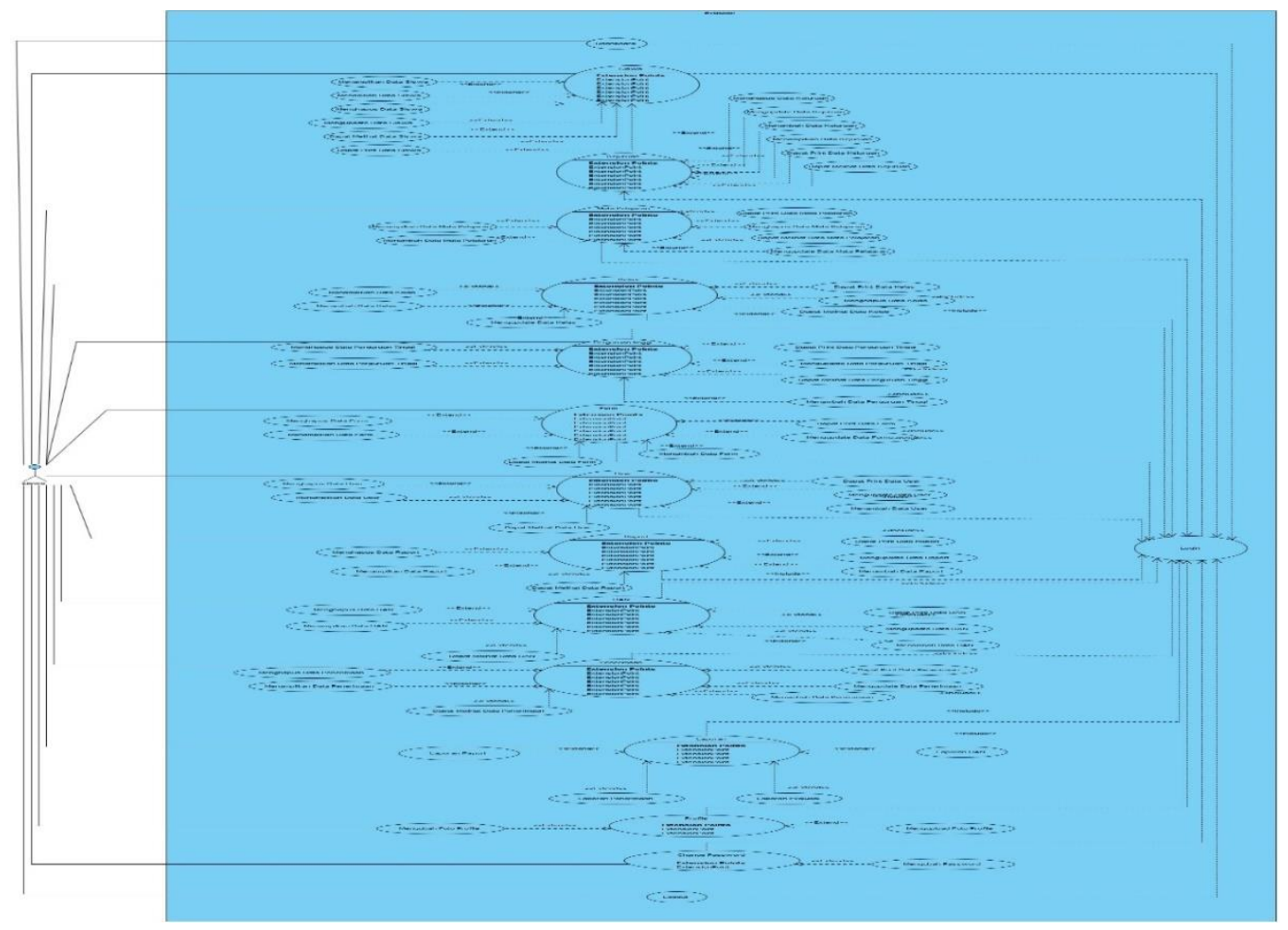

Gambar 5. Use Case Diagram

Berdasarkan gambar use case diagram usulan (gambar 5) terlihat jelas bahwa terdapat 16 (enam belas) yaitu dashboard, siswa, kejuruan, mata pelajaran, perguruan tinggi, form, user, raport, uan, penerimaan, raport detail, uan detail, penerimaan, profile, change password, login, dan logout

Use case diagram sebagai bentuk rancangan sistem yang akan diciptakan (gambar 5) merupakan desain model tampilan utama yang berorientasi pada kebutuhan menu aplikasi yang disiapkan, selain itu untuk kebutuhan penyimpanan informasi data agar dapat digunakan secara histori juga digambarkan dalam bentuk class diagram (gambar 4) lengkap dengan informasi field dan type data sesuai kebutuhan penyimpanan data. Serta use case login yang merupakan akses awal untuk masuk ke dalam sebuah sistem berdasarkan informasi data username dan password.

\section{IMPLEMENTASI}

\section{Rancangan Basis Data}

Untuk dapat menggambarkan bentuk basis data secara utuh, peneliti penggunakan aplikasi microsoft access sebagai bentuk gambaran dasar, dan pada akhirnya bentuk rancangan basis data ini dapat disesuaikan menggunakan apa saja sesuai kebutuhan.

\section{a. Tabel Master: Siswa}

Primary Key : nisn

Foreign Key : -

Structure Tabel : \{ nisn, nama, alamat, tanggal_lahir, tempat_lahir, jenis kelamin, no_kejuruan \} 


\begin{tabular}{|c|c|c|c|c|c|c|c|c|}
\hline & $\#$ & Name & Type & Collation & Attributes & Null & Default Comments & Extra \\
\hline$\square$ & 1 & nisn & $\operatorname{int}(10)$ & & & No & None & AUTO_INCREMENT \\
\hline$\square$ & 2 & nama & $\operatorname{varchar}(30)$ & latin1_swedish_ci & & Yes & None & \\
\hline$\square$ & 3 & alamat & text & latin1_swedish_ci & & Yes & None & \\
\hline$\square$ & 4 & tanggal_lahir & date & & & Yes & None & \\
\hline$\square$ & 5 & tempat_lahir & $\operatorname{varchar}(125)$ & latin1_swedish_ci & & Yes & None & \\
\hline$\square$ & 6 & jenis_kelamin & varchar(11) & latin1_swedish_ci & & Yes & None & \\
\hline$\square$ & 7 & no_kejuruan & $\operatorname{int}(11)$ & & & No & None & \\
\hline
\end{tabular}

Tabel 1. Struktur

\section{b. Tabel Master: Kejuruan}

Primary Key : no_kejuruan

Foreign Key : :

Structure Tabel : \{no_kejuruan, nama_kejuruan, keterangan \}

\begin{tabular}{|c|c|c|c|c|c|c|c|c|}
\hline & $\#$ & Name & Type & Collation & Attributes & Null & Default Comments & Extra \\
\hline$\square$ & 1 & no_kejuruan & $\operatorname{int}(11)$ & & & No & None & AUTO_INCREMENT \\
\hline$\square$ & 2 & nama_kejuruan & $\operatorname{varchar(5)}$ & latin1_swedish_ci & & Yes & None & \\
\hline ( & 3 & keterangan & text & latin1_swedish_ci & & Yes & None & \\
\hline
\end{tabular}

Tabel 2. Struktur Kejuruan

\section{c. Tabel Master: Mata Pelajaran}

Primary Key : no_mp

Foreign Key : -

Structure Tabel : \{no_mp, nama_mp, keterangan $\}$

$\begin{array}{llllll}\text { \# } & \text { Name } & \text { Type } & \text { Collation } & \text { Attributes } & \text { Null Default Comments Extra } \\ \square & 1 & \text { no_mp } & \text { int(2) } & \text { No } & \text { None } \\ \square & 2 & \text { nama_mp } & \text { varchar(50) latin1_swedish_ci } & \text { No } & \text { None } \\ \square & 3 & \text { keterangan text } & \text { latin1_swedish_ci } & \text { No } & \text { None }\end{array}$

Tabel 3. Stuktur Mata Pelajaran

\section{d. Tabel Master: Penerimaan}

Primary Key : no_penerimaan

Foreign Key : -

Structure Tabel : \{ no_penerimaan, nisn, no_perguruan,

Tahun, jalur \}

\begin{tabular}{|c|c|c|c|c|c|c|c|c|}
\hline & $\#$ & Name & Type & Collation & Attributes & Null & Default Comments & Extra \\
\hline$\square$ & 1 & no_penerimaan & $\operatorname{int}(11)$ & & & No & None & AUTO_INCREMENT \\
\hline$\square$ & 2 & nisn & $\operatorname{int}(10)$ & & & No & None & \\
\hline$\square$ & 3 & no_perguruan & $\operatorname{int}(11)$ & & & No & None & \\
\hline$\square$ & 4 & tahun & year(4) & & & Yes & None & \\
\hline$\square$ & 5 & jalur & $\operatorname{varchar}(7)$ & latin1_swedish_ci & & Yes & None & \\
\hline
\end{tabular}

Tahel 4. Struktur Penerimaan

\section{e. Tabel Master: Perguruan Tinggi}

Primary Key : no_perguruan

Foreign Key : -

Structure Tabel : \{ no_perguruan, nama_perguruan, alamat \} 


\begin{tabular}{|c|c|c|c|c|c|c|c|c|}
\hline & $\#$ & Name & Type & Collation & Attributes & Null & Default Comments & Extra \\
\hline$\square$ & 1 & no_perguruan & $\operatorname{int}(11)$ & & & No & None & AUTO_INCREMENT \\
\hline$\square$ & 2 & nama_perguruan & $\operatorname{varchar}(125)$ & latin1_swedish_ci & & Yes & None & \\
\hline$\square$ & 3 & alamat & text & latin1_swedish_ci & & Yes & None & \\
\hline
\end{tabular}

Tabel 5. Struktur Perguruan Tinggi

\section{f. Tabel Transaksi: Raport}

Primary Key : no_raport, nisn

Foreign Key : -

Structure Tabel : \{no_raport, nisn, tahun, semester, tanggal \}

\begin{tabular}{llllll} 
\# & Name & Type & Collation Attributes & Null Default Comments Extra \\
\hline 1 & no_raport & int(11) & No None & AUTO_INCREMENT \\
\hline 2 & nisn & $\operatorname{int}(10)$ & No None & \\
$\square$ & 3 & tahun & year(4) & Yes None \\
$\square$ & 4 & semester & int(1) & Yes None \\
\hline & tanggal & date & Yes None
\end{tabular}

Tabel 6. Struktur Raport

\section{g. Tabel Transaksi: Raport Detail}

Primary Key : no_raport

Foreign Key : -

Structure Tabel : \{no_raport, no_mp, nilai \}

\begin{tabular}{|c|c|c|c|c|c|c|}
\hline & $\#$ & Name & Type & Collation Attributes & Null & Default Comments \\
\hline$\square$ & 1 & no_raport ? & $\operatorname{int}(11)$ & & No & None \\
\hline$\square$ & 2 & no_mp & $\operatorname{int}(2)$ & & No & None \\
\hline$\square$ & 3 & nilai & $\operatorname{decimal}(3,0)$ & & Yes & None \\
\hline
\end{tabular}

Tabel 7. Struktur Raport Detail

h. Tabel Transaksi: UAN

Primary Key : no_uan

Foreign Key : : -

Structure Tabel : \{no_uan, nisn, tahun, tanggal \}

\begin{tabular}{|c|c|c|c|c|c|c|c|c|}
\hline & \# & Name & Type & Collation & Attributes & Null & Default Comments & Extra \\
\hline$\square$ & 1 & no_uan & $\operatorname{int}(11)$ & & & No & None & AUTO_INCREMENT \\
\hline$\square$ & 2 & nisn & $\operatorname{varchar}(10)$ & latin1_swedish_ci & & No & None & \\
\hline$\square$ & 3 & tahun & year(4) & & & Yes & None & \\
\hline$\square$ & 4 & tanggal & date & & & Yes & None & \\
\hline
\end{tabular}

Tabel 8. Struktur UAN

i. Tabel Transaksi: UAN Detail

Primary Key : no_uan

Foreign Key : -

Structure Tabel : \{ no_uan, no_mp, nilai $\}$

\begin{tabular}{|lllll} 
\# & Name & Type & Collation Attributes & Null Default Comments Extra \\
$\square$ & 1 & no_uan & int(11) & No None \\
$\square$ & 2 & no_mp & int(2) & No None \\
\hline & 3 & nilai & decimal $(3,0)$ & Yes None
\end{tabular}

Tabel 9. Struktur UAN detail 


\section{Grafik Monitoring Evaluasi Kelulusan Siswa}

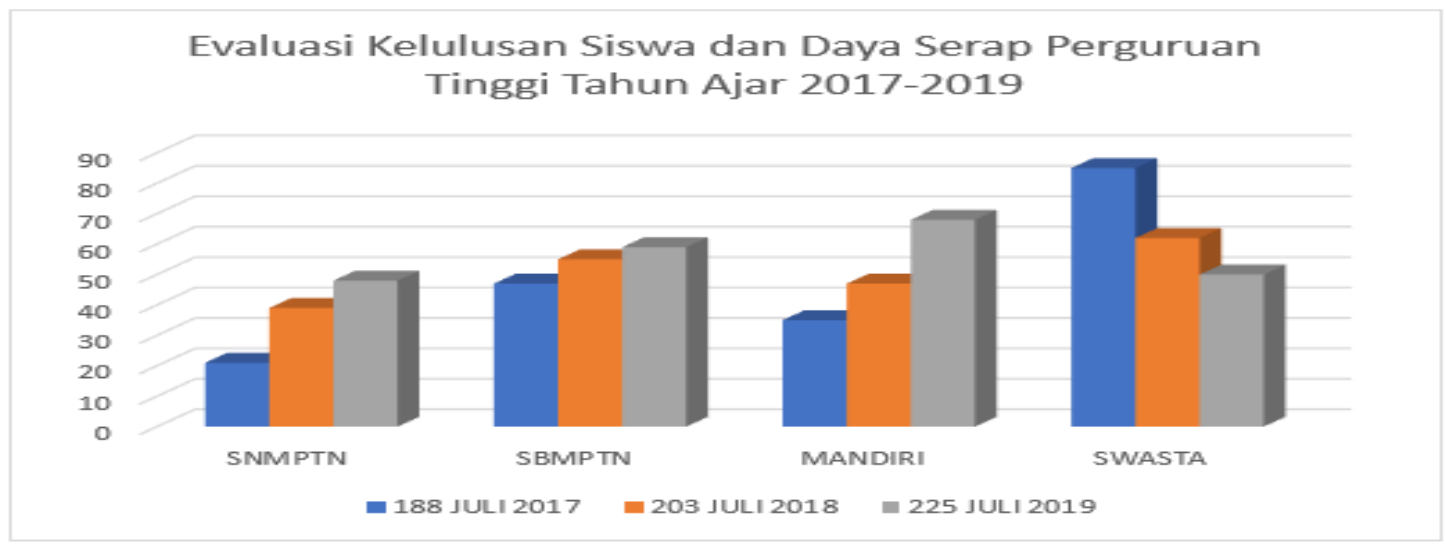

Gambar 6. Grafik Evaluasi Kelulusan Siswa dan Daya Serap Perguruan Tinggi Tahun 2017-2019

Grafik diatas (gambar 6) merupakan grafik evaluasi kelulusan siswa dan daya serap perguruan tinggi berdasarkan tahun ajaran. Hal ini bisa membantu manajemen dalam menunjang keputusan guna pembayaran mana yang menjadi prioritas pembayaran. Grafik diatas bisa diambil berdasarkan Datewarehouse, sebagaimana di definisikan "Doing Data Warehouse (DW) to your business or system is not only think about the trend only, but how to understand the DW knowledge itself and how to implement it" [11]. Dan bagaimana cara mengukurnya "Measures are a standard unit used to express the size, amount, or degree of something, qualities are often difficult to be measured as it needs to have some certain parameter or elements, and those parameters must be quantifiable and verifiable" [12]

\section{Diagram HIPO}

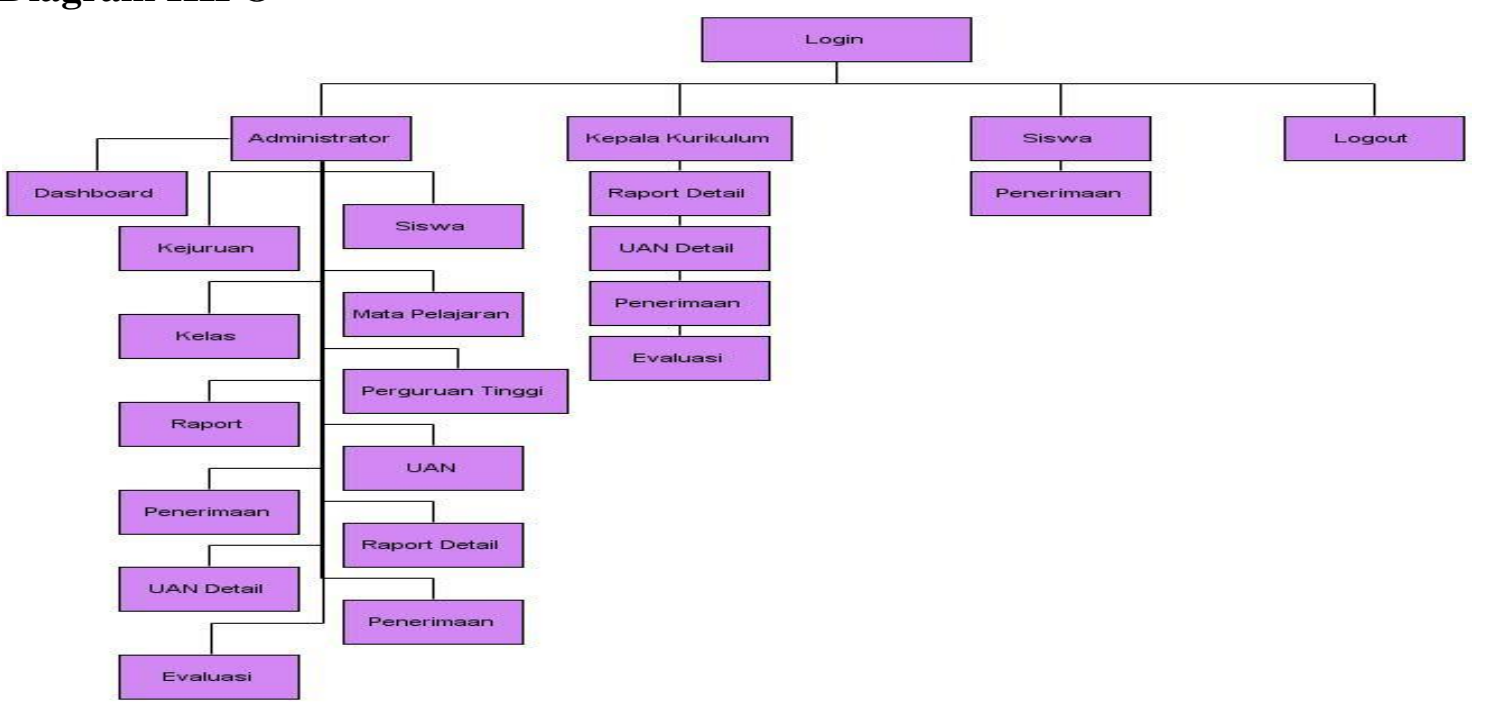

Gambar 7. Diagram HIPO 
Untuk menggambarkan stuktur menu dari sistem yang dirancang dapat digambarkan dengan diagram HIPO (Hierarchy Input Process Output). Untuk

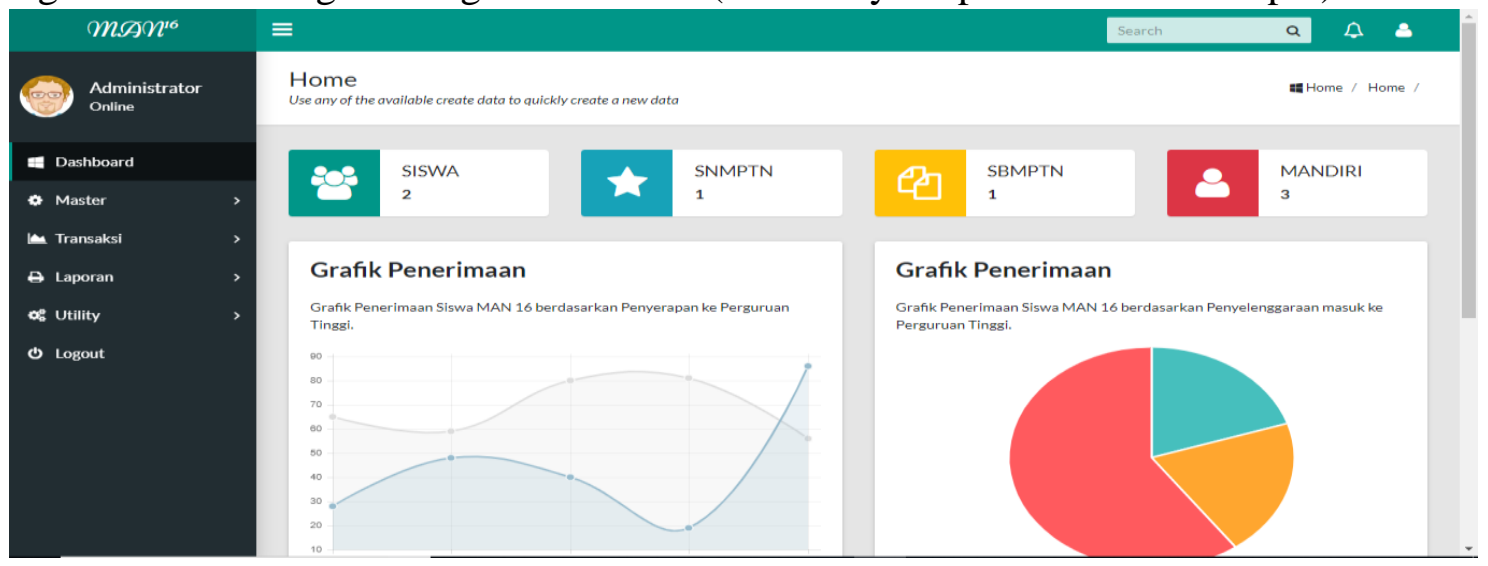

Gambar 8. Tampilan Dashboard

menyediakan suatu struktur guna memahami fungsi-fungsi dari program. Terlihat dari diagram HIPO diatas (gambar 7) terdapat 1 (satu) fungsi utama yaitu login (digram 0) dan 5 (lima) fungsi dibawahnya, yaitu fungsi menu dashboard (diagram 1), menu data master (diagram 2), menu data transaksi (diagram 3), menu data laporan (diagram 4) dan menu logout (diagram 5). Didalam fungsi menu data master (diagram 2)

\section{Rancangan Tampilan}

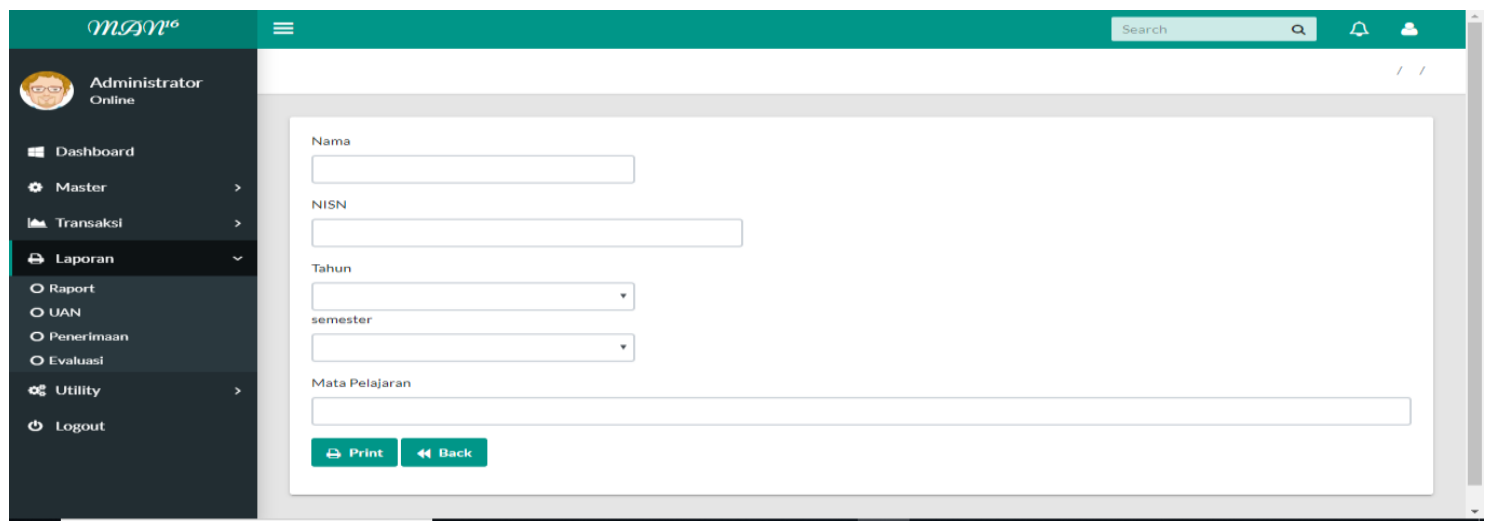

Terlihat pada tampilan layar diatas (gambar 8) merupakan tampilan layar utama yang terdiri dari menu master, menu transaksi dan menu laporan.

\section{Query Penciptaan Informasi}

\section{Query Function Tambah UAN:}

function uan_list()

\{ \$sql="select * from tbl_uan";

\$this->sql=\$sql;

$\$ \mathrm{i}=0$;

$\$$ query=\$this->mysqli->query $(\$$ sql) or die ( $\$$ this->mysqli->error () );

while (\$result=\$query->fetch_assoc () )

\{ \$this->no_uan[\$i]=\$result['no_uan'];

\$this->nisn[\$i]=\$result['nisn'];

\$this->tahun[\$i]=\$result['tahun']; 


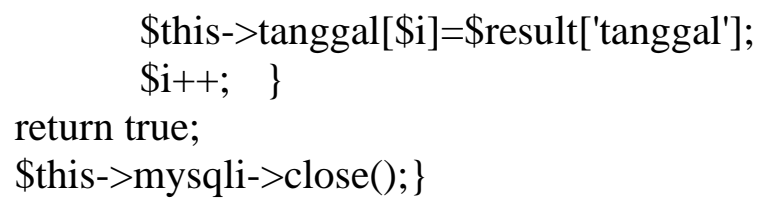

\section{Query Function Select:}

function uan_select()

\{ \$sql="select * from tbl_uan where no_uan='".\$this->no_uan."'";

\$this->sql $=\$$ sql;

\$query=\$this->mysqli->query $(\$$ sql) or die (\$this->mysqli->error () );

while (\$result=\$query->fetch_assoc ()$)$

\{

\$this->no_uan=\$result['no_uan'];

$\$$ this $->$ nisn $=\$$ result['nisn'];

\$this->tahun $=\$$ result['tahun'];

\$this- $>$ tanggal $=\$$ result['tanggal'];

return true; \$this->mysqli->close ()$;\}$

\section{Query Function Update:}

function uan_update()

$\{$ \$sql="update tbl_uan

set

no_uan='".\$this->no_uan."',

nisn="'.\$this->nisn."',

tahun='".\$this->tahun."',

tanggal="'.\$this->tanggal."

where no_uan='".\$this->no_uan."'";

$\$$ query=\$this->mysqli->query $(\$$ sql) or die ( $\$$ this->mysqli->error ()$)$;

return true;

\$this->mysqli->close ();

\section{KESIMPULAN}

Berdasarkan hasil analisa dan penelitian yang dilakukan, maka penulis menyimpulkan bahwa proses evaluasi penilaian dan serta daya serap perguruan tinggi saat ini masih manual, sehingga menyebabkan proses menjadi tidak efektif dan efisien. Hal ini terlihat dari lamanya waktu yang dibutuhkan, mulai dari proses pencatatan data, sampai dengan pembuatan laporan, selain itu juga menyebabkan tingkat keakuratan yang rendah, karena masih terdapat beberapa kesalahan perhitungan. Untuk mengatasi permasalahan diatas, sistem yang diusulkan mampu berjalan secara terkomputerisasi sehingga membuat proses evaluasi penilaian serta daya serap lulusan di perguruan tinggi menjadi efektif dan efisien, selain itu juga mampu menciptakan laporan hasil penilaian dan laporan penerimaan siswa pada perguruan tinggi dengan cepat dan akurat menggunakan beberapa metode analisa dan perancangan yang penulis lakukan

\section{DAFTAR PUSTAKA}

[1] Junaidi, J., Roji, A., \& Munawar, K. (2015). Konsep Otomatisasi Sistem Pembayaran SPP Online Untuk Mengurangi Tingkat Keterlambatan. Proceedings Konferensi Nasional Sistem dan Informatika (KNS\&I).. 
[2] Menurut Anita (2017), "Penilaian merupakan proses pengumpulan dan pengolahan informasi untuk mengukur pencapaian hasil belajar peserta didik".

[3] Junaidi, J., Effendy, M. Y., \& Hartono, H. (2015). REKAYASA MODEL APLIKASI SISTEM PRODUCT KNOWLADGE UNTUK MENDUKUNG PENGAMBILAN KEPUTUSAN DALAM MENENTUKAN KINERJA KARYAWAN. CERITA Journal, 1(1), 46-55.

[4] Menurut Juita dalam Astin Tiara Pratiwi Sunardi, dkk (2015:8), "kualitas dapat diartikan sebagai tingkat atau ukuran kesesuaian suatu produk dengan pemakainya, dalam arti sempit kualitas diartikan sebagai tingkat kesesuaian produk dengan standar yang telah ditetapkan.

[5] Junaidi, J., Sutrisno, S., \& Janah, K. (2019). MODEL APLIKASI PURCHASING SYSTEM UNTUK MONITORING STOK DALAM MENGURANGI TINGKAT KERUGIAN. SENSI Journal, 5(1), 86-98.

[6] Menurut Kotler dalam Titien Alawiyah (2018:806), "Kualitas adalah keseluruhan ciri dan sifat dari suatu produk atau pelayanan yang berpengaruh pada kemampuannya untuk memuaskan kebutuhan yang dinyatakan atau yang tersirat.

[7] Junaidi, J., Setianingsih, R., \& Khotimah, K. (2015). Rancang Bangun Sistem Penerimaan Dan Pengeluaran Barang Menggunakan Java Aplikasi. Proceedings Konferensi Nasional Sistem dan Informatika (KNS\&I)..

[8] Martono, A., \& Junaidi, D. Y. IMULATION GAME BASED ON JARIMAGIC METHOD TO CALCULATE MORE QUICKLY FOR ELEMENTARY STUDENTS.

[9] Junaidi, J., Cholisoh, N., \& Hasanah, N. (2018). Rancang Bangun Sistem Manajemen Aset IT Untuk Pencatatan History Maintenance Sebagai Pendukung Keputusan. SENSI Journal, 4(2), 220-231..

[10] M. Subekti, Warnars Junaidi, H.L.H.S., Y. Heryadi, "The 3 steps of best data warehouse model design with leaning implementation for sales transaction in franchise restaurant", Cybernetics and Computational Intelligence (CyberneticsCom) 2017 IEEE International Conference on, 20-22 Nov 2017.

[11] J. Junaidi, A. Julianto, N. Anwar, S. Safrizal, H.L.H.S. Warnars, K. Hashimoto, "Perfecting a Video Game with Game Metrics", Telkomnika, vol. 16, no. 3, pp. 1324-1331, June 2018 